\title{
Observations of suspended matter along the Dutch coast
}

\author{
C.M. van der Hout ${ }^{1}$, T. Gerkema ${ }^{1}$, J. Nauw ${ }^{1}$ and H. Ridderinkhof ${ }^{1}$ \\ ${ }^{1}$ Physical Oceanography, Royal Netherlands Institute for Sea Research (NIOZ), P.O. Box 59, 1790 AB, Den Burg (Texel), The \\ Netherlands, carola.van.der.hout@nioz.nl
}

\begin{abstract}
Large amounts of suspended matter are transported through the Dutch coastal zone in the southern North Sea. Current estimates, based on budget studies, are in the order of 15-20 Mton per year transported in northward direction, which should take place in a small strip of $5-10 \mathrm{~km}$ wide. For this study we have performed a series of measurements on total suspended matter in an area in the most northerly extent of the Rhine region of fresh water influence. The measurements focused on observations both in the vertical and in the horizontal on the behavior of suspended matter in the nearshore zone up to $7 \mathrm{~km}$ from the shoreline. A peak in bottom concentrations is observed close to the coast along the coastal stretch. This hot spot location is found in the cross-shore direction at about $1.5 \mathrm{~km}$ from the coastline at a water depth of $15 \mathrm{~m}$. Here, total suspended matter concentrations near the bottom exceed $200 \mathrm{mg} / 1$. These peak concentrations have not been identified before and add to the suggestion that a large part of the northward suspended matter transport occurs very close to the coast.
\end{abstract}

\section{INTRODUCTION}

The Dutch coastal zone forms a transport path of total suspended matter (TSM) from the Strait of Dover to the Wadden Sea and the Norwegian Trench. On the basis of budget studies, it is estimated that half of the yearly-averaged 30 - 40 Mton from the Strait of Dover is transported along the Belgian and Dutch coast in a small strip of $5-10 \mathrm{~km}$ wide. No sources and sinks are present along the Belgian and Dutch coast that significantly alter the estimated 15 - 20 Mton/yr [De Kok, 2004; Fettweis et al., 2007]. Main sinks are the Wadden Sea and the Norwegian Trench. Total suspended matter concerns all particles suspended in the water column, being a mixture of silt, clay and organic matter. Inorganic particles are normally smaller than $63 \mu \mathrm{m}$, but organic material can grow to sizes $>200 \mu \mathrm{m}$. TSM affects primary production by reducing light penetration in the water column, but also by distributing nutrients and organic material. For the Wadden Sea suspended matter is an important contributor for the habitat, e.g. mud content of the shoals, and primary productivity. Nauw and Ridderinkhof [2009] calculated an import of 5 - $10 \mathrm{Mton} / \mathrm{yr}$ into the Wadden Sea through the Marsdiep Inlet. This figure is large compared to the current estimate of $15-20 \mathrm{Mton} / \mathrm{yr}$ along the Dutch coast.

TSM measurements in the Dutch coastal zone are scattered both in time and in space. In the 70's and 80's the focus was on in-situ surface samples of a large area [Visser et al., 1991], in the 90's on the vertical distribution done with in-situ observations with optical instruments and with high time resolution [Joordens et al., 2001; McCandliss et al., 2002], later on extended with acoustic measurements to increase spatial coverage [Merckelbach and Ridderinkhof, 2006], and since the start of the 21 st century surface concentrations with high resolution of a large area can be obtained via satellite images [Eleveld et al., 2008] on time and spatial scales similar to current North Sea numerical models. Our project follows the line started in the 90's in order to include information over the full water column. The focus is on the near-shore zone up to $7 \mathrm{~km}$ offshore, by doing measurements at vertical cross-sections to the coast, and by examining variations over the tidal cycle as well as at larger time scales, up to seasonal. We present measurements made in 2010 in the northern part of the Dutch coastal zone with R.V. Navicula, as part of the NTW3.1 project in Building with Nature.

\section{MEASUREMENTS}

Measurements of total suspended matter (TSM) concentrations, density and current velocities were carried out in spring and autumn 2010 with R.V. Navicula. In this paper we will discuss the results of the cross-sectional measurements done in autumn 2010 on a transect near Egmond aan Zee, $20 \mathrm{~km}$ north of the harbor of IJmuiden, and a time-series of part of a tidal cycle done in spring 2010 at an anchor station near the transect at $1.5 \mathrm{~km}$ from the coastline (figure 1). The data concerns continuously measured velocities with an acoustic Doppler current profiler (ADCP), complemented with CTD-casts and water samples taken for

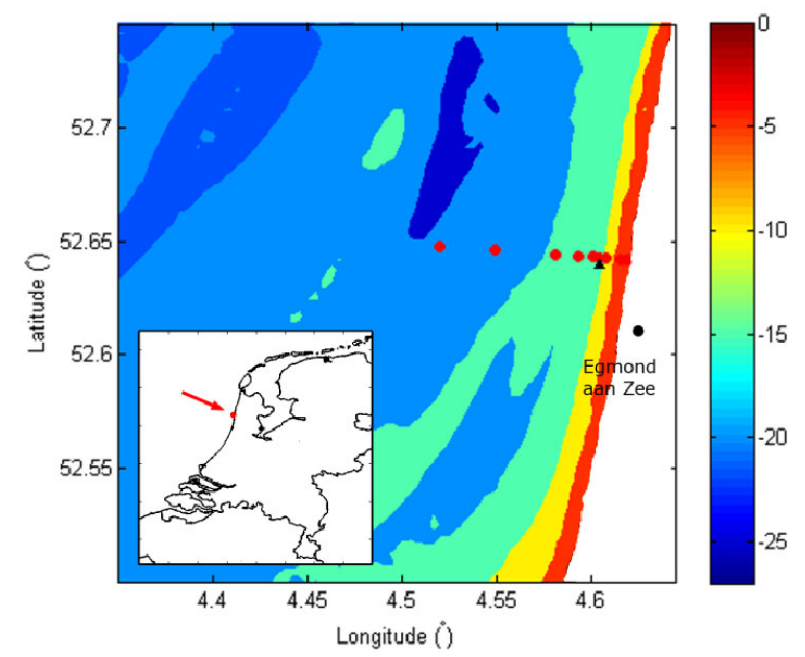

Figure 1. Location of the stations on the transect (red dots) and of the anchor station (black triangle) on the coast of NorthHolland. Water depths are in meters below mean sea level. 
calibration on stations. At the anchor station the time interval between CTD-casts was 20 minutes. The transect runs from 0.5 $\mathrm{km}$ until $7 \mathrm{~km}$ from the coastline, with irregularly spaced stations at $0.5,1,1.5,2,3,5$ and $7 \mathrm{~km}$ from the shoreline. The transect was measured on 2010/10/26 during spring tides, average wind force of $5 \mathrm{Bft}$ from the southwest and average wave height of $1.5 \mathrm{~m}$. One week later, on 2010/11/01, the same transect was measured with an extra station at $1.25 \mathrm{~km}$ from the shoreline - during neap tides, under mild meteorological conditions and an average wave height of $0.30 \mathrm{~m}$. Details of the cruise days relevant to this paper are given in Table 1.

The current velocity measurements were done with a vesselmounted downward looking RDI 1.2 MHz ADCP attached to the side of the ship at a water depth of $1 \mathrm{~m}$. Data was stored with an interval of $2 \mathrm{~s}$ with 4 pings per ensemble. The bin height was 0.5 $\mathrm{m}$ and blanking distance $0.5 \mathrm{~m}$. At the stations a vertical profile of temperature, salinity, density and optical backscatter was made by lowering a lightweight frame with a Seabird SBE 911plus CTD and a Seapoint OBS from the afterdeck until it would hit the bottom. Only data of the downcast are used for analysis, because of the downward CT-configuration on the frame. The raw data were filtered from peaks, averaged over $25 \mathrm{~cm}$ bins and filtered with a running mean over 3 bins.

The optical backscatter sensor (OBS), hereafter called $\mathrm{OBS}_{\text {frame}}$, was calibrated with in-situ samples of total suspended matter concentrations. At low scattering values a linear relation can be established between the instruments' voltage and the TSM concentrations [Downing, 2006]. At each station two water samples were taken with a 51 Niskin bottle; one at about $1 \mathrm{~m}$ above the bottom and one at $1 \mathrm{~m}$ below the surface. Two subsamples were taken from each sample while stirring thoroughly. The first subsample of a volume between 0.2 and 0.81 was used to determine the sediment concentration, by 3 bar backpressure filtering over a pre-weighed $0.7 \mu \mathrm{m}$ glassfiber Whatman filter. The filters were directly rinsed with demi-water to remove the salts and were stored for transport to the lab.
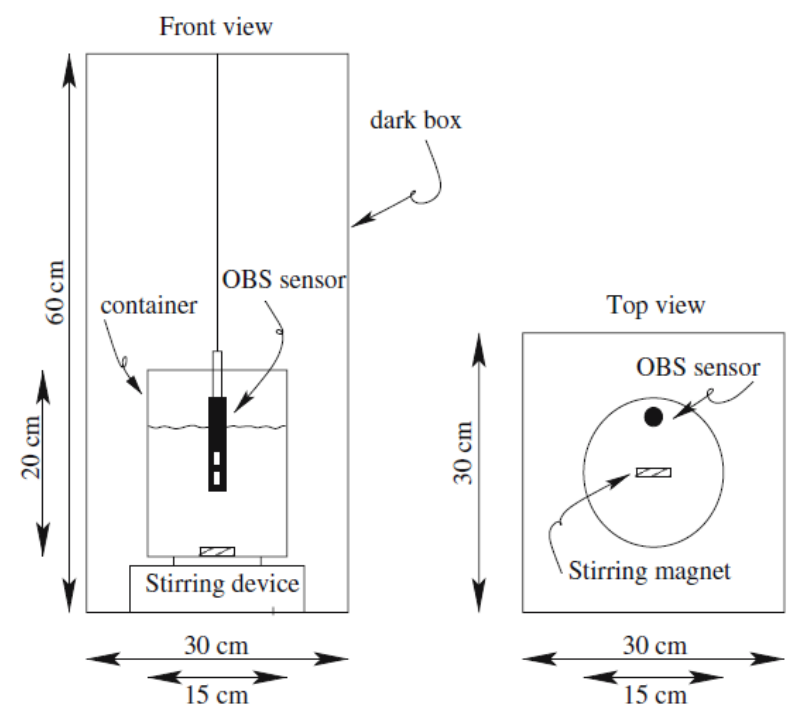

Figure 2. Configuration of voltage measurement of a Seapoint optical backscatter sensor (OBS) in a dark box [Merckelbach and Ridderinkhof, 2006].
Afterwards, the filters were dried at $110^{\circ}$ for 2 hours and weighed to determine the concentration of the water sample. The second subsample of 21 is placed in a dark box, where another OBS, hereafter called $\mathrm{OBS}_{\mathrm{box}}$, was placed in the sample (Figure 2). The particulate matter was kept in suspension with a magnetic mixer. When stable, the voltage of the $\mathrm{OBS}_{\text {box }}$ was notated. The calibration graph of $\mathrm{OBS}_{\mathrm{box}}$ versus total suspended matter concentration gives a linear relationship shown in figure 3 for the spring measurements and the autumn measurements separately. In spring the range of concentrations observed was between 15 and $210 \mathrm{mg} / \mathrm{l}$, while this was between 3 and $70 \mathrm{mg} / \mathrm{l}$ in autumn. The figure shows some scatter as a result of measurement inaccuracies, but with an $\mathrm{R}^{2}$ of 0.95 a reliable relationship is established for the spring measurements:

$$
\mathrm{TSM}=37.11 \cdot \mathrm{OBS}_{\mathrm{box}}+3.21
$$

and with an $\mathrm{R}^{2}$ of 0.94 for the autumn measurements:

$$
\mathrm{TSM}=30.24 \cdot \mathrm{OBS}_{\mathrm{box}}-3.70
$$

The two lines deviate from each other by an offset of $7 \mathrm{mg} / \mathrm{l}$ and an angle. This might be attributed to the difference in TSM composition in spring and autumn. Particles of different material and with a different shape reflect the infrared light of an OBS in a slightly different manner [Downing, 2006]. This implies calibration of the OBS as described above during each cruise.

The $\mathrm{OBS}_{\mathrm{box}}$ and the $\mathrm{OBS}_{\text {frame }}$ are also linearly correlated. This relationship is established by performing two CTD-casts in the measurement area on the 26th of October with both instruments attached to the CTD-frame. Data are used from both upcast and downcast, as the signal from an OBS is not influenced by cast direction. The relationship reads:

$$
\mathrm{OBS}_{\mathrm{box}}=1.21 \cdot \mathrm{OBS}_{\text {frame }}+0.02 \text {. }
$$

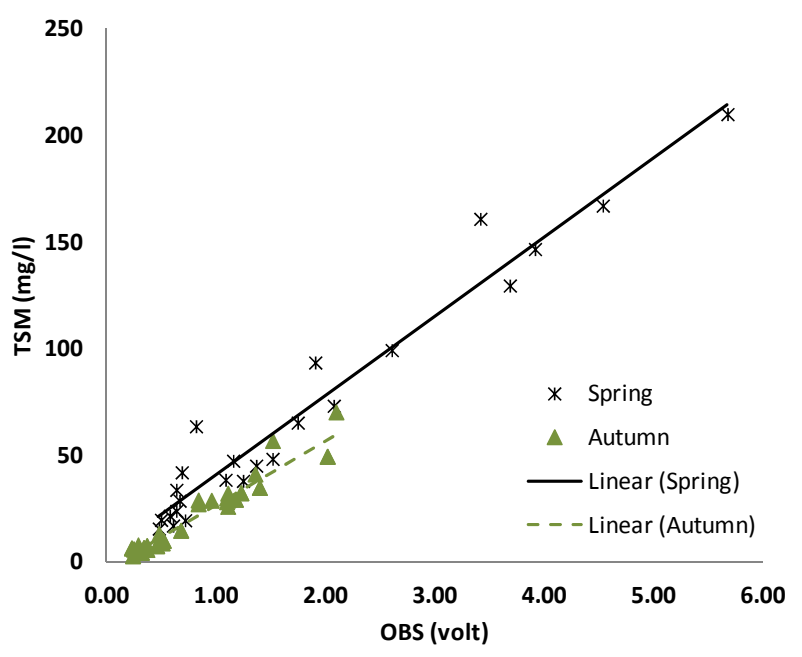

Figure 3. Calibration graph of the optical backscatter sensor (OBS) in the dark box with total suspended matter (TSM) concentration samples for the spring measurements (black line, black crosses) and the autumn measurements (green dashed line, green triangles). 
Table 1: Averaged wind, wave and tidal conditions during the measurement periods. Winds are recorded at IJmuiden harbor by the Royal Netherlands Meteorological Institute and waves at IJmuiden munitiestortplaats by the Ministry of Transport, Public Works and Water Management.

\begin{tabular}{cccccccc}
\hline Date & Type & Season & $\begin{array}{c}\text { Mean wind } \\
\text { force }(\mathrm{Bft})\end{array}$ & $\begin{array}{c}\text { Wind } \\
\text { direction }\left(^{0}\right)\end{array}$ & $\begin{array}{c}\text { Wind direction with } \\
\text { respect to coastline }\end{array}$ & $\begin{array}{c}\text { Wave } \\
\text { height }(\mathrm{m})\end{array}$ & Spring - Neap \\
\hline $2010 / 03 / 29$ & $\begin{array}{c}\text { Anchor } \\
\text { station }\end{array}$ & Spring & 3 & 179 & Alongshore from south & 1.0 & intermediate \\
$2010 / 10 / 26$ & Transect & Autumn & 5 & 216 & Alongshore from south & 1.5 & Spring \\
$2010 / 11 / 01$ & Transect & Autumn & 1 & 66 & O fshore & 0.3 & Neap \\
\hline
\end{tabular}

The linear relation contains a small offset, probably due to the scatter of the data. The deviation of the angle from 1 has to do with the different age of both sensors. The OBS sensors used are known to age over time. With formulas (1), (2) and (3) the $\mathrm{OBS}_{\text {frame data }}$ of vertical profiles are converted to TSM concentration.

\section{RESULTS}

The cross-sectional views of the concentration distribution of the two transects are shown in Figures $4 \mathrm{a}$ and 5a. Both transects were measured during the phase of slack tide after high water. Highest concentrations of $60 \mathrm{mg} / \mathrm{l}$ in the first week and $40 \mathrm{mg} / \mathrm{l}$ in the second week are found at $1.5 \mathrm{~km}$ from the shoreline near the bottom at a water depth of $15 \mathrm{~m}$. These concentrations are not remarkably high as most of the sediments have settled from the water column during the slack phase of the tide. The first transect was measured during a higher turbulent kinetic energy (TKE) period than the second transect. Both tides and waves determine
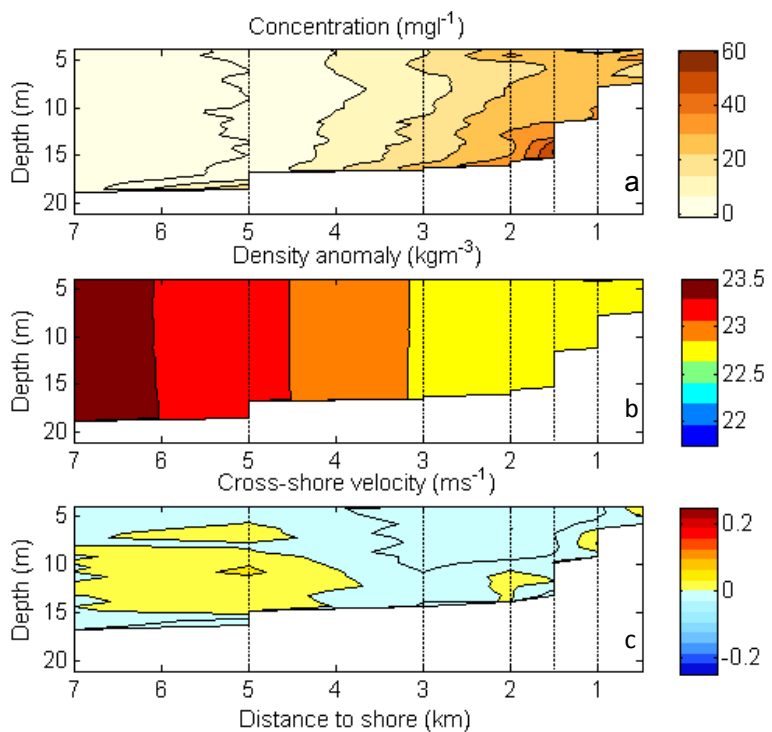

Figure 4. Cross-section perpendicular to the coast of TSM concentration, density-1000 $\mathrm{kgm}^{-3}$ and cross-shore velocities (positive in shoreward direction) at CTD casts (vertical dashed lines) on 2010/10/26. Contour lines of concentration are spaced at $7.5 \mathrm{mgl}^{-1}$, of density anomaly at $0.25 \mathrm{kgm}^{-3}$ and of velocity at $0.025 \mathrm{~ms}^{-1}$. the level of turbulent kinetic energy in this area and thereby the distribution of TSM in the water column [Joordens et al., 2001]. This explains the higher maximum concentration and the overall higher concentrations measured during the first week compared with the second week. In the first week the total volume of suspended matter in the transect was 3 times more than in the second week.

The density distribution in Figure $4 \mathrm{~b}$ shows well-mixed waters with a horizontal density gradient, with fresher waters close to the shore. The relatively high energy level as a result of waves and spring tides keeps the water column vertically mixed and suppresses a haline cross-shore circulation (Figure 4c). In the second week, under low TKE conditions, the density distribution shows a completely different picture (Figure 5a). Besides a stronger horizontal density difference, the water column is also vertically stratified as much as $0.8 \mathrm{psu}$ at the station furthest offshore. In the cross-shore velocity transect (Figure 5c) a clear upwelling event is seen as a result of both the estuarine circulation as well as the mild offshore directed wind. This upwelling event is
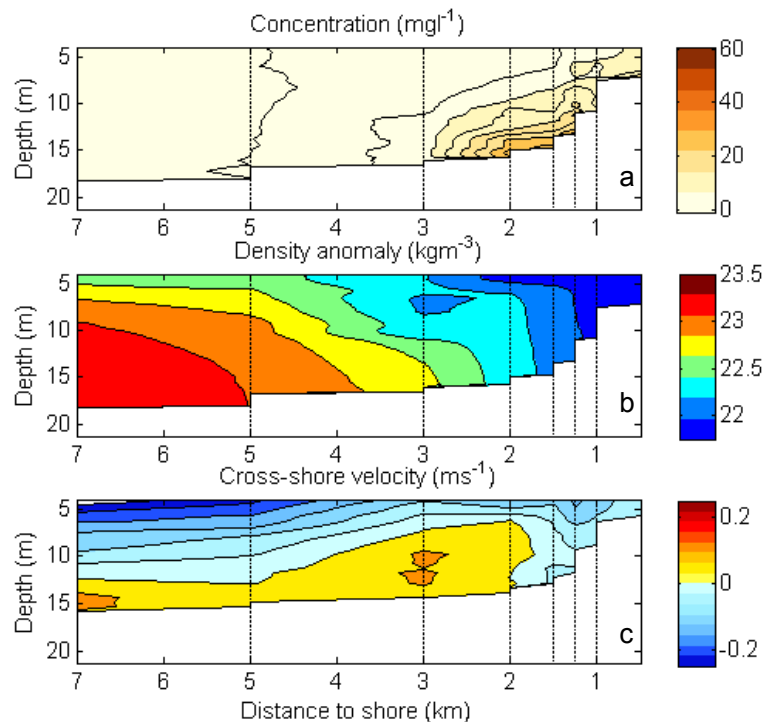

Figure 5. Cross-section perpendicular to the coast of TSM concentration, density-1000 $\mathrm{kgm}^{-3}$ and cross-shore velocities (positive in shoreward direction) at CTD casts (vertical dashed lines) on 2010/11/01. Contour lines of concentration are spaced at $7.5 \mathrm{mgl}^{-1}$, of density anomaly at $0.25 \mathrm{kgm}^{-3}$ and of velocity at $0.050 \mathrm{~ms}^{-1}$. 
characteristic for the Rhine region of fresh water influence, though it is less likely to occur further downstream from the Rhine outflow [De Boer et al., 2009].

A time series over part of a tidal cycle is shown in Figure 6. The 4-hour time series was started just before slack after low water, and ends after maximum flood velocity. The water level lags the sea surface height with 45 minutes, indicating the progressive character of the tidal wave in this area. The location of the anchor position is at $1.5 \mathrm{~km}$ from the shoreline (Figure 1), which is in the area of highest TSM concentrations, according to Figures 4 and 5 . Figure 6 shows the evolution of the TSM concentration as a function of depth and depth-averaged northward velocity. In

general, concentrations increase from the surface to the bottom. Although vertically smoothed, the profiles still show sharp vertical variations and sudden clouds of TSM. Two individual maxima are observed at 11:30 and 13:30. The peak at 11:30 is probably still a remainder of the resuspension by the ebb velocity prior to the start of the measurements. At 13:00 hours UTC, which is one hour after slack tide, concentrations obtain their minimum value due to settling of TSM from the water column. The settling process of suspended matter takes some time leading to a time lag between current velocity and TSM concentration with decreasing currents. The maximum concentration is attained about 45 minutes before the maximum flood velocity in a small layer near the bottom. Resuspension of the recently settled sediments is started. Thereafter, the temporarily settled sediment is resuspended further throughout the water column, decreasing the maximum concentration near the bottom. If only local resuspension and deposition processes would control the volume of total suspended matter in the water column, we would not expect this volume to decrease when flood current velocities maintain strong at 15:00 hours. This indicates that other non-local processes, such as advection in longshore and cross-shore direction are also important in the distribution of TSM in this area.

\section{DISCUSSION AND CONCLUSION}

Hot spots of high TSM concentrations are found at $15 \mathrm{~m}$ depth at a distance of $1.5 \mathrm{~km}$ offshore of Egmond aan Zee. Such hot sport are also found on a similar location in a transect $12 \mathrm{~km}$ south and a transect $10 \mathrm{~km}$ north of Egmond aan Zee, measured in similar periods. This particular location (1.5 km offshore and $15 \mathrm{~m}$ depth) and such high concentrations $(>200 \mathrm{mg} / \mathrm{l}$ ) have not been identified before along the Dutch coast. Similar research programs focused on an area further offshore, partly because research vessels with a draught of 4-5 m cannot safely operate in this shallow area. R.V. Navicula only has a draught of $1 \mathrm{~m}$ and can therefore perform measurements in this area not surveyed before, though safe operation is severely limited by a wave height of 1.5 m.

Turbulence, produced by the tide and meteorological conditions, does not appear to affect the location of the hot spot. This is shown by two transects at the same location measured during different levels of TKE (Figures 4 and 5), though it does increase the total volume in suspension with increasing turbulence as observed in previous studies [Joordens et al., 2001; McCandliss et al., 2002; Fettweis et al., 2006]. Other processes are more likely to maintain the hot spot location whilst diffusion spreads it out in the cross-shore. A possible process concerns the temporary storage on/in the seabed on time scales of the diurnal tidal cycle, the spring-neap tidal cycle and the seasonal cycle. During calm periods - slack tide, neap tide and summer - sediments are accumulated on/in the bed, where bottom processes may rework the material. Preliminary comparison of Ensis Directus densities (razor clams) with TSM bottom concentrations show a positive correlation. At the hot spot location, highest densities of Ensis Directus in the cross-shore are observed. These bivalves might filter TSM from the water column, rework the sediment or change the cohesive properties of the particles. It is thought that these bivalves have a positive effect on the burial of suspended matter in the bed, though this still has to be verified.

Another process concerns the haline cross-shore circulation measured on the 1st of November 2010 (Figure 5c). Visser et al. [1991] used the estuarine type of circulation in the coastal zone to explain a persistent TSM surface minimum at $25 \mathrm{~km}$ from the Dutch coastline as was found in the '70s and' 80 s dataset of Rijkswaterstaat. The circulation - due to the horizontal density gradient in the coastal zone (Figures $4 b$ and $5 b$ ) - drives surface waters in an offshore direction and bottom waters in an onshore direction perpendicular to the tidal current. This bottom current then transports TSM in the bottom layer in a coastward direction. Why the hot spot location is not closer to the coast could be related to the shallowness of the area shoreward of the hot spot location. There, processes such as wave driven currents start to play a role, bed shear stresses increase and the bed slope gradient increases and with it the gravitational component within the transport equations.

If these hot spots exist at all times - as they appear to do from the results presented in this paper - then they may contribute significantly to the total northward TSM transport. Whether this will change the current estimate of $20 \mathrm{Mton} / \mathrm{yr}$ will be subject of further study of observations in this area. However, these measurements do provide more insight in processes transporting large amounts of TSM. This will lead to better assessment of effects of coastal construction works on the natural transport of TSM.

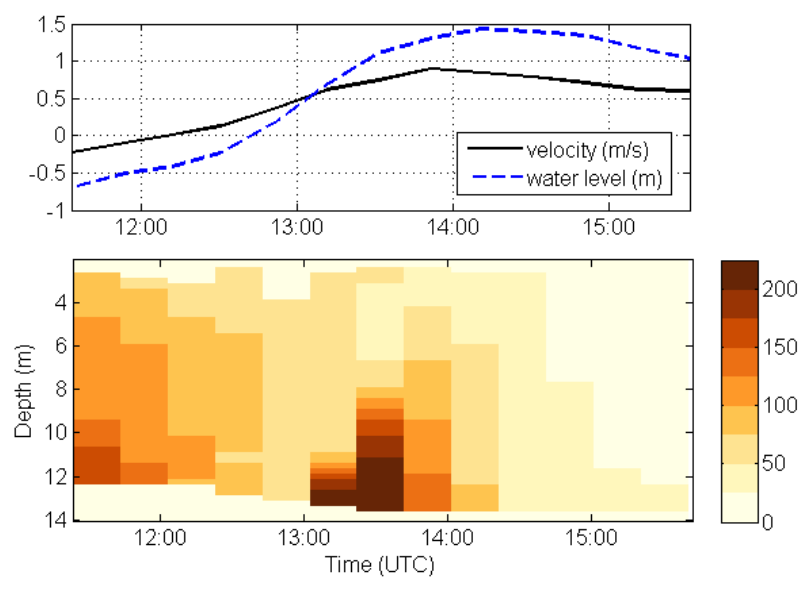

Figure 6. Time-series of depth averaged northward alongshore velocity and water level (top) and concentration over the vertical (bottom). Measured at an anchor station $1.5 \mathrm{~km}$ from the shoreline at Egmond aan Zee on the $29^{\text {th }}$ of March 2010 with a 20-minutes interval. 


\section{ACKNOWLEDGEMENTS}

We gratefully acknowledge the captain and crew of R.V. Navicula as well as the volunteers for their contribution of this research. This research is carried out within the research program Building with Nature, as part of the project NTW3.1.

\section{REFERENCES}

Boer, G. J. de, J. D. Pietrzak, and J. C. Winterwerp (2009), SST observations of upwelling induced by tidal straining in the Rhine ROFI, Continental Shelf Research, 29, 263-277, doi:10.1016/j.csr.2007.06.011.

Downing, J. (2006), Twenty-five years with OBS sensors: The good, the bad, and the ugly, Continental Shelf Research, 26(1718), 2299-2318, doi:10.1016/j.csr.2006.07.018.

Eleveld, M. A., R. Pasterkamp, H. J. van der Woerd, and J. D. Pietrzak (2008), Remotely sensed seasonality in the spatial distribution of sea-surface suspended particulate matter in the southern North Sea, Estuarine, Coastal and Shelf Science, 80(1), 103-113, doi:10.1016/j.ecss.2008.07.015.

Fettweis, M., F. Francken, V. Pison, and D. Van den Eynde (2006), Suspended particulate matter dynamics and aggregate sizes in a high turbidity area, Marine Geology, 235, $63-74$, doi:10.1016/j.margeo.2006.10.005.

Fettweis, M., B. Nechad, and D. Van den Eynde (2007), An estimate of the suspended particulate matter (SPM) transport in the southern North Sea using SeaWiFS images, in situ measurements and numerical model results, Continental Shelf Research, 27(10-11), 1568-1583, doi:10.1016/j.csr.2007.01.017. [online] Available from:
Joordens, J. C. A., A. J. Souza, and A. Visser (2001), The influence of tidal straining and wind on suspended matter and phytoplankton distribution in the Rhine outflow region, Continental Shelf Research, 21(3), 301-325, doi:10.1016/S0278-4343(00)00095-9.

Kok, J. M. de (2004), Slibtransport langs de Nederlandse kust. Bronnen, fluxen en concentraties. Report RIKZ/OS/2004.148w, Ministry of Transport, Public Works and Water Management (Rijkswaterstaat).

McCandliss, R. R., S. E. Jones, M. Hearn, R. Latter, and C. F. Jago (2002), Dynamics of suspended particles in coastal waters (southern North Sea) during a spring bloom, Journal of Sea Research, 47(3-4), 285-302, doi:10.1016/S13851101(02)00123-5.

Merckelbach, L. M., and H. Ridderinkhof (2006), Estimating suspended sediment concentration using backscatterance from an acoustic Doppler profiling current meter at a site with strong tidal currents, Ocean Dynamics, (56), 153-168, doi:10.1007/s10236-005-0036-z.

Nauw, J., and H. Ridderinkhof (2009), Slibtransport door het Marsdiep op basis van veerbootmetingen, NIOZ-Report 2009-7, Royal NIOZ.

Visser, M., W. P. M. de Ruijter, and L. Postma (1991), The distribution of suspended matter in the Dutch coastal zone, Netherlands Journal of Sea Research, 27(2), 127-143. 